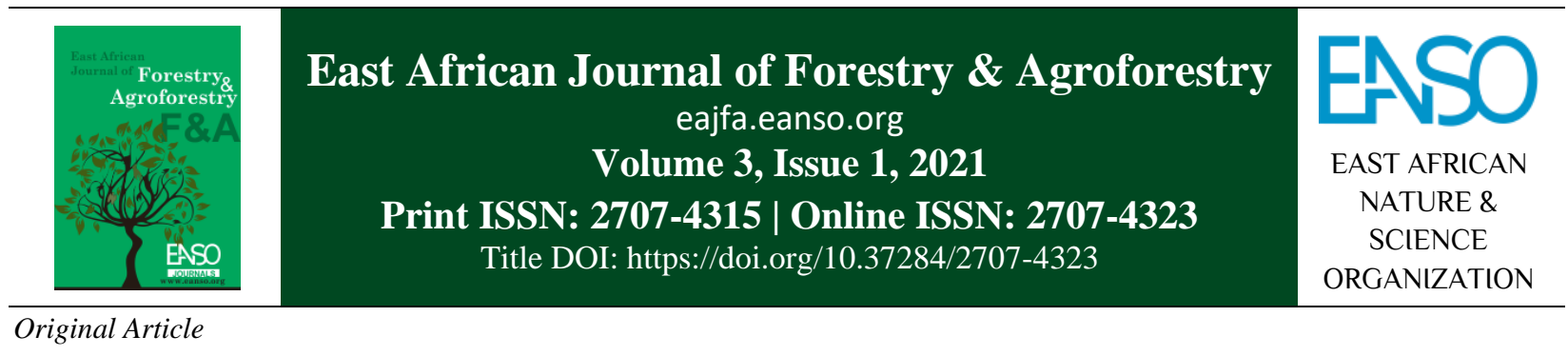

\title{
Sustainable Human-Wildlife Conflict Management Strategies Around Busitema Central Forest Reserve, Eastern Uganda.
}

\author{
Remigio Turyahabwe ${ }^{l}$, Joyfred Asaba ${ }^{2 *}$, Andrew Mulabbi ${ }^{2}$, \& Makoba Gudoyi Paul ${ }^{1}$ \\ ${ }^{1}$ Department of Geography, Faculty of Science and Education Busitema University, P. O. Box 236, Tororo, Uganda. \\ ${ }^{2}$ Department of Geography and SST, Faculty of Arts and Social Sciences, Kyambogo university, P. O. Box 1, Kyambogo, \\ Uganda. \\ ${ }^{3}$ Department of Humanities, Faculty of Education, Muni University, P. O. Box 725 Arua, Uganda. \\ * ORCID: https://orcid.org/0000-0002-2977-7548; Author for Correspondence email: asabajoyfred@ yahoo.com.
}

Article DOI: https://doi.org/10.37284/eajfa.3.1.423

Date Published: ABSTRACT

04 October 2021 The study aimed at establishing sustainable Human-wildlife co-existence strategies to help settle the conflicts existing between humans and wildlife

Keywords: living around Busitema Central Forest Reserve. To achieve this, we first examined the nature of the existing conflicts which helped us to come up with conflict-specific co-existence strategies. We used questionnaires, interviews and focused group discussions, where the information obtained was confirmed by field observations. The data was then analysed using simple descriptive statistics like percentages, means and standard deviations. Results indicated that primates (baboons and monkeys) dominated the conflicting list of wildlife with humans followed by rodents while carnivores were the least reported. Crop raiding (100\%), livestock and poultry predation (36\%) were the most dominant conflicts reported posed to man while habitat destruction (40\%) and road accidents (26\%) were the biggest conflict man has posed on wildlife. Equitable compensation $(10 \pm 0.0)$ and community involvement in conservation $(8 \pm 1.4)$ dominated the sustainable Human-Wildlife coexistence strategies suggested by local communities. It was concluded that, involvement of local communities in wildlife conservation should be prioritized and areas surrounding the protected forest area should be planted with crops such as tea and trees such as eucalyptus (woodlots) that are not affected by wildlife but rather are enhancers of wildlife habitats.

\section{APA CITATION}

Turyahabwe, R., Asaba, J., Mulabbi, A., Paul, M. G. (2021). Sustainable Human-Wildlife Conflict Management Strategies Around Busitema Central Forest Reserve, Eastern Uganda East African Journal of Forestry and Agroforestry, 3(1), 62-76. https://doi.org/10.37284/eajfa.3.1.423

62 This work is licensed under a Creative Commons Attribution 4.0 International License. 


\section{CHICAGO CITATION}

Turyahabwe, Remigio., Joyfred Asaba, Andrew Mulabbi, \& Makoba Gudoyi Paul. 2021. "Sustainable Human-Wildlife Conflict Management Strategies Around Busitema Central Forest Reserve, Eastern Uganda". East African Journal of Forestry and Agroforestry 3 (1), 62-76. https://doi.org/10.37284/eajfa.3.1. 423.

\section{HARVARD CITATION}

Turyahabwe, R., Asaba, J., Mulabbi, A., \& Paul, M. G. (2021), "Sustainable Human-Wildlife Conflict Management Strategies Around Busitema Central Forest Reserve, Eastern Uganda”, East African Journal of Forestry and Agroforestry, 3(1), pp. 6276. doi: 10.37284/eajfa.3.1. 423.

\section{IEEE CITATION}

R. Turyahabwe, J. Asaba, A. Mulabbi, \& M. G. Paul, "Sustainable Human-Wildlife Conflict Management Strategies Around Busitema Central Forest Reserve, Eastern Uganda", EAJFA, vol. 3, no. 1, pp. 62-76, Oct. 2021.

\section{MLA CITATION}

Turyahabwe, Remigio., Joyfred Asaba, Andrew Mulabbi, \& Makoba Gudoyi Paul. "Sustainable Human-Wildlife Conflict Management Strategies Around Busitema Central Forest Reserve, Eastern Uganda". East African Journal of Forestry and Agroforestry, Vol. 3, no. 1, Oct. 2021, pp. 62-76, doi:10.37284/eajfa.3.1. 423.

\section{INTRODUCTION}

Globally the struggle to alleviate poverty often comes with conflicting loyalties between use and conservation of natural resources more so, wild/environmental biodiversity and the land resources they occupy (Mekonen, 2020). In LDCs where population growth has resulted into shortage of land for both settlement and agriculture, this has forced humans to encroach on the fragile and reserved wildlife ecosystems such as forests and National parks (McNally et al., 2017). Under such circumstances human communities surrounding these protected areas have looked at wildlife conservation as a constraint to their socio-economic wellbeing. This creates thinking among the rural communities that conservation is one of the causes of land shortage. (Peterson et al., 2010, Faulhaber et al., 2008). As such, the lands occupied by these protected areas have been interpreted as idle and wasted lands that deserve to be used for agriculture and settlement (Faulhaber et al., 2008). On the other hand, aggressive primates such as baboons, monkeys, chimpanzees in the conserved areas/lands have either stealthily or boldly attacked humans, strayed in their crop gardens surrounding conserved areas, preyed on both poultry and domestic animals. These interaction between wildlife and people results into conflicts which negatively impact on people and their resources, or wild animals and their habitat (Ogada, et al, 2003; Faulhaber et al., 2008).

Human-wildlife conflicts, defined as any interaction between humans and wildlife, which results into negative effects on people and wildlife (McNally et al., 2017), are not a recent phenomenon, it has occurred throughout man's prehistory and recorded history and exist as long as humans and wild animals share the same landscapes and resources (Vijayan \& Pati, 2002). Humanwildlife conflict is considered severe when wildlife starts to claim people's lives, causing loss of property such as livestock and poultry, straying and destroying crop gardens. Stubborn primates tend to attack and steal very young children of humans, scare young children going to their junior schools (Erxleben et al., 2011). All these have limited local support for conservation of such wildlife. The conflict is further escalated by increasing human population adjacent to wildlife habitats that leads to increase in demand for resources such as land for settlement and agriculture, fuel wood, herbs which increases frequency and intensity of encroachment on wildlife habitats. In return, the wild animals that cannot adapt to the altered habitats end up straying in human habitats, marginal habitats or reducing in number (Lusk et al., 2009)

63 This work is licensed under a Creative Commons Attribution 4.0 International License. 
In Africa, changes in human population and land use patterns have led to increasing overlap of critical areas of conservation importance and widespread elimination/extinction of primates from their previous rangelands despite their ecological and economic importance to humans. This is particularly true for the 13 species of primates and small mammals in the Nyungwe Forest Reserve of Rwanda which are linked to intractable forms of conflict with the rural human communities (Peterson et al., 2010). In eastern Africa, Humanwildlife conflict is found associated with most reserved rangelands such as; forest reserves and national parks as is the case with Masai-Mara (Kenya), Nyungwe forest reserve (Rwanda), Bwindi impenetrable forest (Uganda) where wild game move to communal areas causing havoc to human life and property while in retaliation, humans kill them physically or by poisoning them (McNally et al., 2017).

In an effort to tackle the problem, the custodians of the protected areas in Uganda namely NFA (National Forestry Authority (NFA) and Uganda Wildlife Authority (UWA) agitated for evacuation of the local communities around the forest reserves to a minimum of $1 \mathrm{~km}$ radius off the forests' boundaries (NEMA, 2008). Such bottom-up strategies by conservation authorities excluded the local people, thereby creating resentment among them. This reduced the effectiveness of the conservation approach and contributed to the reoccurrence of illegal activities. As a result of the shortcomings of this protective approach to conservation, a new approach known as collaborative wildlife management that emphasis involvement of the local people in management of the protected areas has been impressed in the country (Saito, 2007). The rationale behind the collaborative approach is that by working together, people are able to achieve more than organizations, working on their own, and involving those affected is likely to induce cooperation and improve perception by the local people towards conservation activities (Forgie et al, 2001).

But despite adoption of collaborative management strategies to mitigate the incidence of these humanwildlife conflicts in Uganda and around Busitema forest reserve in particular, the conflicts have continued to escalate. In fact, according to NEMA (2018), the total population and number of primate families especially baboons and monkeys in forest reserves, including Busitema Central Forest Reserve, have reduced. This reduction was partly attributed to encroachment on the forest by the local human communities who seem to have killed a number of them in a conflict. This situation has consequently created the need to re-evaluate the current wildlife management practices in this area with a view to address unresolved challenges that limit the subsequent change of perceptions of the local people towards wild life management. Previous studies on this subject have concentrated on national parks found in savanna climatic and vegetation zones, more so, on elephants and chimpanzees. Yet different animals and species cause different types of damages and conflicts with humans at different times of the year.

Thus, to ensure sustainable management of wildlife in forest ecosystems in Uganda and Busitema forest in particular, it is necessary to understand the present human wildlife conflicts around Busitema forest and to investigate community's awareness of the current human-wildlife conflict management strategies with a view to providing sustainable human-wildlife Co-existence strategies around Busitema Central Forest Reserve.

\section{MATERIALS AND METHODS}

\section{Description of the Study Area}

Busitema Central Forest Reserve is located in eastern Uganda in the district of Busia, about $297 \mathrm{~km}$ by road from Kampala on the Kampala - Tororo high way. It is located between $34^{0} 12^{\prime} 0 \mathrm{E}$ and $34^{0} 14^{\prime} 0 \mathrm{E}$ and $0^{0} 28^{\prime} 30 \mathrm{~N}$ and $0^{0} 28^{\prime} 43 \mathrm{~N}$ (Figure 1). 
It covers a surface area of approximately $25 \mathrm{Km}^{2}$ of land with an average altitude of 1106 M.A.S.L. It was established as a central forest reserve by the 2001 policy of NFA in the year. Its establishment targeted conservation of primates like baboons and rare monkey species. The forest is also a home of other small mammals like bats, squirrels as well as reptiles such as snakes, pythons and some amphibians. A number of avian species are also found in this forest reserve. The forest reserve has a variety of habitats that support a variety of wild life species. For example, part of the forest is more of a woodland, grass land, thickets, while the rest and biggest part is dominated by true dense tropical forest tree vegetation species. The protected area is famous in Uganda for its immense important primate area composing of more than 3 species of baboons and 3 species of endemic monkeys of afrotropical lowland biome species. Busitema Central Forest Reserve receives a bi-modal rain fall pattern between march-June and November-December. The annual rainfall ranges between $1200-1500 \mathrm{~mm}$. Many areas on the fringes of the forest reserve have high agricultural potential and cultivation is wide spread. The human population in Busia district has increased rapidly to 15,291 people in 2014 Uganda National housing and population census

\section{Figure 1: Location of Busitema Central Forest Reserve in Busia District}

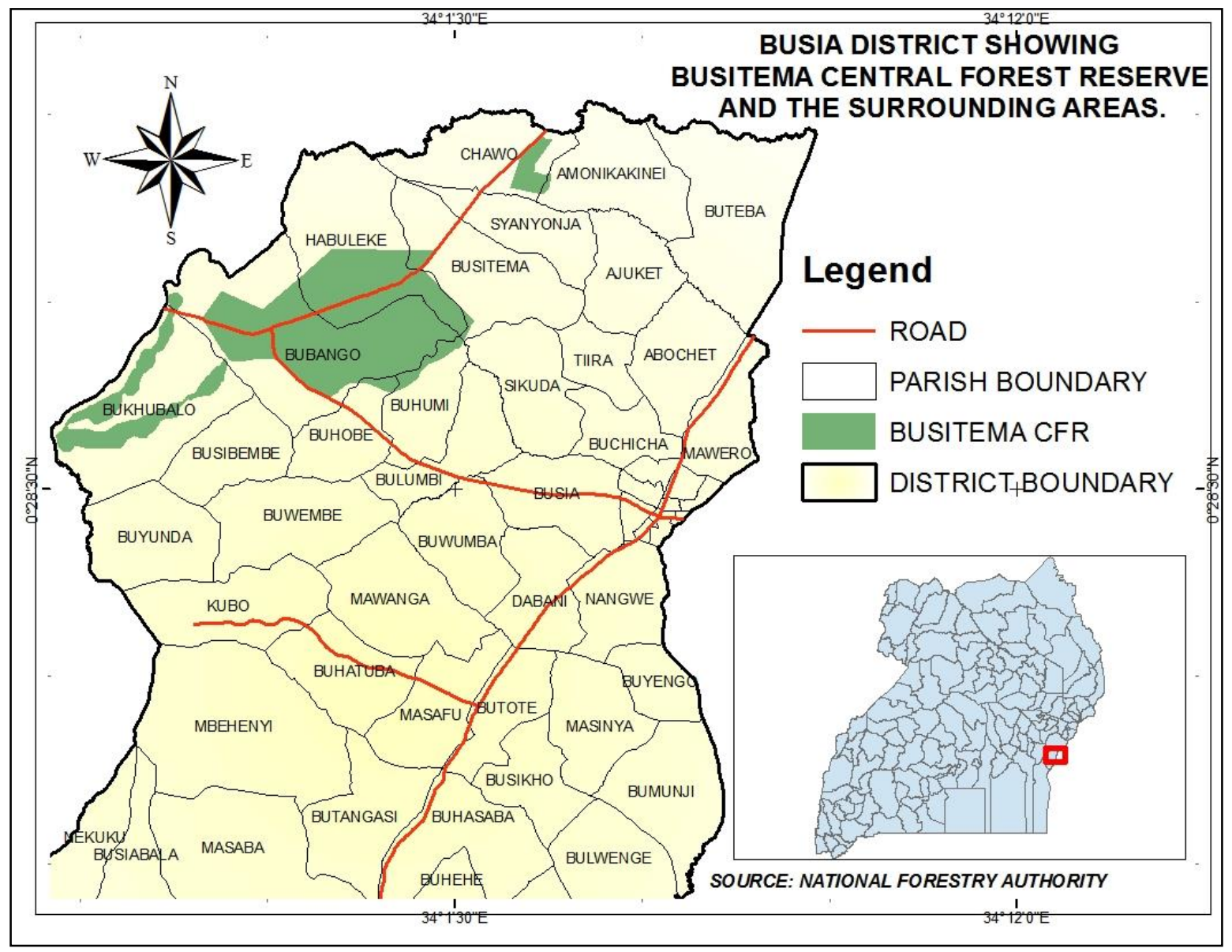

\section{Data Collection}

We collected data from primary and secondary sources. Secondary data sources included internet, text books, journal articles, NFA, NEMA (National Management Authority) and UWA periodical and annual reports about expected wildlife population 
and taxa distribution in protected areas of Uganda and their management policies. Primary data was collected from the surrounding local rural households using questionnaires, interviews and field observations to gain insights about the nature of Human-Wildlife Conflicts and possible sustainable co-existence strategies aimed at reducing conflicts.

The study adopted purposive, clustered and random sampling designs. 1NFA, 1UWA and 1district environment officers were purposively selected for interview because they are the primary custodians of the wildlife conservation. The study considered all the 10 parishes surrounding the forest reserve within $2 \mathrm{Km}$ radius from the forest edges to outside the forest. Each parish was considered as a cluster. In each cluster, 10 households were randomly selected for interview. In each household the head of the family was purposively selected as one who is knowledgeable. Where the head of family was absent, any adult above 18 yrs was opted for.

Interviews were held with informants mentioned above to explore the nature of Human-Wildlife Conflict and how best humans can co-exist with wildlife in Busitema Central Forest Reserve. Focus group discussions helped us to gain insights about opinions, attitudes and knowledge of local communities regarding Human-Wildlife Coexistence strategies. We used field observations to relate and confirm information accuracy from questionnaire and interview responses.

Table 1: Frequency of occurrence of the conflicts
We trained and recruited local assistants (1 per parish) to assist in the administration of questionnaires to address the specific needs of this study. Questionnaires were administered to mature people above 18yrs of age. In all, 100 questionnaires were completed with the response rate of $100 \%$. The questionnaires targeted information relating to socio-demographic data, nature of Human-Wildlife Conflicts, interaction with Wildlife and how best humans can co-exist positively with wildlife. Respondents were specifically questioned about recent experience with Human-Wildlife Conflict incidents (e.g., crop raiding, livestock and poultry predation, human injury and death). Questionnaires, interviews, discussions were made between December 2020 and June 2021 and responses were translated into English language.

\section{Data Analysis}

Data obtained from questionnaires, discussions, interviews and field observations were analysed qualitatively and quantitatively using simple descriptive statistics like percentages, mean and standard deviations, graphs and tables.

\section{RESULTS AND DISCUSSIONS}

\section{Frequency of Occurrence the Human-Wildlife Conflicts}

The respondents were asked to state how frequent they experienced human-wildlife conflicts. The results are presented in Table 1.

\begin{tabular}{ll}
\hline Time & Percentage \\
\hline Annually & 11 \\
Seasonally & 46 \\
Monthly & 23 \\
Weekly & 3 \\
Daily & 12 \\
Not Sure & 5 \\
Total & $\mathbf{1 0 0}$ \\
\hline
\end{tabular}


The results reveal that $46 \%$ of the respondent reported that they experienced conflicts with animals on a seasonal basis, $11 \%$ had these conflicts annually, 23\% said these occurred monthly, $12 \%$ said it as daily occurrence and 5\% were not so sure of the frequency of these conflicts. The varying responses depend on when the individual faced the wildlife conflict. In the study area, majority experience kind of conflict on a seasonal basis, this mainly relates to crops raids by animals. This Naughton Treves (2005) who associated the occurrence and frequency of human wildlife conflict specially the crop-raiding as dependents upon the availability, variability and type of food sources in the area, the level of human activity on a farm, and the type and maturation time of crops as compared to natural food sources. Crop farming in the area is a seasonal activity commanded by climatic characteristics of the green belt zone where people have two planting seasons.

\section{Type of Problem Animals that Dominate Human-wildlife Conflicts}

Variety of animals dominate the human-wildlife conflicts in Busitema Central Forest Reserve as shown in Table 2. 
Table 2: Number of people conflicting with different wildlife around Busitema Central Forest Reserve per Parish

\begin{tabular}{|c|c|c|c|c|c|c|c|c|}
\hline \multirow{3}{*}{$\begin{array}{l}\text { PARISH } \\
\text { (cluster) }\end{array}$} & \multicolumn{8}{|c|}{ Number of people conflicting with different wildlife species around Busitema Central Forest Reserve per parish. } \\
\hline & \multicolumn{2}{|c|}{ Baboon Species } & \multicolumn{2}{|c|}{ Monkey Species } & Carnivore Species & \multicolumn{3}{|c|}{ Rodent Species } \\
\hline & $\begin{array}{l}\text { (Papio } \\
\text { anubis) } \\
\text { Olive } \\
\end{array}$ & $\begin{array}{l}\text { Papio } \\
\text { cynocephalus }\end{array}$ & Vervet & $\begin{array}{l}\text { Black and white } \\
\text { (Colubus) }\end{array}$ & $\begin{array}{l}\text { Brown } \quad \text { Hyena } \\
\text { (Hyaena brunnea) }\end{array}$ & $\begin{array}{l}\text { Mongoose } \\
(\text { H. Hirtula })\end{array}$ & $\begin{array}{l}\text { Squirrel } \\
\text { (Hystrix } \\
\text { cristata) }\end{array}$ & $\begin{array}{l}\text { Wild ra } \\
\text { (chyoryctus } \\
\text { splendens) }\end{array}$ \\
\hline Habuleke & 10 & 8 & 5 & 4 & 2 & 1 & - & 2 \\
\hline Bubango & 10 & 9 & 2 & 5 & - & - & - & - \\
\hline Buhobe & 10 & 9 & 7 & - & 1 & - & - & 6 \\
\hline Buhumi & 6 & 5 & - & 2 & - & - & - & 7 \\
\hline Bukhubalo & - & - & - & 7 & 3 & - & - & 3 \\
\hline Sikuda & 7 & - & - & - & 5 & 3 & - & - \\
\hline Busitema & 10 & 10 & 7 & 6 & 2 & 4 & 2 & - \\
\hline Amonikakeni & - & - & 8 & 10 & 1 & - & 9 & 6 \\
\hline Chawo & 5 & - & 8 & 9 & - & 2 & 6 & - \\
\hline Syanyonja & - & - & 2 & 1 & 1 & - & 3 & 4 \\
\hline $\begin{array}{l}\text { Total } \\
\text { respondents' } \\
\text { complaints }\end{array}$ & 58 & 41 & 39 & 44 & 15 & 10 & 20 & 28 \\
\hline Percentage & 58 & 41 & 39 & 44 & 15 & 10 & 20 & 28 \\
\hline
\end{tabular}


From Table 2, baboons were reported to be the most harmful wild animal affecting the people around Busitema Central Forest Reserve with a total frequency of 99. Respondents reported the Papio anubis species of baboons to be affecting 7 parishes (70\%) of the area studied. $100 \%$ of the respondents in the parishes of Habuleke, Bubango, Buhobe and Busitema indicated that baboons are a problem to their socio-economic wellbeing. Bukhubalo did not have any complaint about baboons. Colubus (black and white) monkey species harmed most the parish of Amonkakeni. Sikuda parish was not affected by any monkey species. From Table 1, it can be seen that where the baboons dominated, the monkeys were few, while where the monkeys dominated like in Syanyonja, Chawo and Amonikakeni the baboons were few. Hyenas tormented outskirts of the forest in Sikuda and Bukhubalo where the grass and thickets dominated the vegetation. This was pasture for domestic herbivores. Rodents were dominant in the parishes of Busitema, Amonikakeni, Chawo and Synyonja. The most dominant rodent species was Hystrix cristata but only found in four parishes. The mongoose were reported by only 10 respondents (10\%) Table1. Despite being at the centre of the forest reserve, Bubango parish was not affected by rodents. Hyenas highly affected Sikuda and Bukhubalo, parishes associated with more domestic animals in the area.

\section{Nature of Human-Wildlife Conflict around Busitema Central Forest Reserve}

The nature of conflicts was divided into two namely; the conflicts caused by animals to humans (man is affected) and conflicts caused by man to wildlife as indicated by humans (how man has affected wildlife). These were summarized in Table 3.

Table 3: The nature of Human-Wildlife Conflict around Busitema Central Forest Reserve.

\begin{tabular}{|c|c|c|c|c|c|c|c|}
\hline \multirow{3}{*}{$\begin{array}{l}\text { Parish } \\
\text { /cluster }\end{array}$} & \multicolumn{7}{|c|}{ Nature of Human-Wildlife Conflict reported in different parishes/clusters } \\
\hline & \multicolumn{3}{|c|}{ Human conflicts with wildlife } & \multicolumn{4}{|c|}{ Wildlife conflicts with humans } \\
\hline & $\begin{array}{l}\text { Crop } \\
\text { raiding }\end{array}$ & $\begin{array}{l}\text { Livestock } \\
\text { and } \\
\text { poultry } \\
\text { predation }\end{array}$ & $\begin{array}{l}\text { Artificial } \\
\text { curfew/human } \\
\text { attack }\end{array}$ & $\begin{array}{l}\text { Road } \\
\text { accidents }\end{array}$ & $\begin{array}{l}\text { Habitat } \\
\text { destruction }\end{array}$ & Poison & $\begin{array}{l}\text { Trapping } \\
\text { in snares } \\
\text { and } \\
\text { physical } \\
\text { killings }\end{array}$ \\
\hline Habuleke & 10 & 9 & 8 & - & 4 & 6 & 5 \\
\hline Bubango & 10 & 10 & 8 & 10 & 4 & 8 & 1 \\
\hline Buhobe & 10 & 2 & - & 3 & - & - & - \\
\hline Buhumi & 10 & 7 & - & - & - & - & - \\
\hline Bukhubalo & 10 & 6 & 2 & 3 & 6 & - & 2 \\
\hline Sikuda & 10 & - & - & 2 & - & - & - \\
\hline Busitema & 10 & 2 & 5 & 8 & 5 & - & 1 \\
\hline Amonikakeni & 10 & - & - & - & 10 & 4 & - \\
\hline Chawo & 10 & - & - & - & 10 & 2 & - \\
\hline Syanyonja & 10 & - & - & - & 1 & - & - \\
\hline $\begin{array}{l}\text { Total } \\
\text { respondent }\end{array}$ & 100 & 36 & 23 & 26 & 40 & 20 & 09 \\
\hline Percentage & 100 & 36 & 23 & 26 & 40 & 20 & 09 \\
\hline
\end{tabular}

\section{Crop Raiding}

This was the dominant conflict reported by respondents. $100 \%$ of the respondents confirmed that animals have raided crops from gardens of human communities around Busitema Central Forest Reserve (Table 3). Animals have studied the 
human interference pattern, so they raid the crop gardens very early in the morning and very late in the evening when humans have not yet reported to or have left the gardens. The crops that are mostly affected include cassava, potatoes, maize and groundnuts. Millet and sorghum are also affected. Different crops are affected differently and at different times of the season. Maize is affected from the time the stalks/stems begin to stand, through the cob-bearing stage up to when the maize is ready for harvesting. Potatoes and cassava are raided by rodents and primates from the time of bearing root tubes. Maize, cassava and Groundnuts are affected by almost all the wild animals including baboons, monkeys and rodents. Millet and rice are the least affected and usually affected by rodents. Rodents move longer distances to attack crops especially in the night while the monkeys and baboons only move shorter distances searching for food from gardens. Their distances are prolonged when the seasons are off and food is scarce. Crops are a chief source of food and income for humans living around Busitema Central Forest Reserve. Wild animals competing for the same crops with human has angered humans who feel the animals must be killed for causing such huge losses to man. The most affected parishes included Busitema, Bubango, Habuleke and Sikuda.

\section{Livestock and Poultry Predation}

Hyaenas were reported in some parishes to be a threat to lambs and kids. Some community members tie sheep and goats around the fringes of the forest reserve where the pasture is greener leaving them there for a whole day to graze. Hyenas find the domestic animals, attack and kill them for food. Two carcasses 1 of a kid and 1 of a lamb preyed on by a hyaena were observed in 2 parishes of Habuleke and Bubango respectively. Mongooses were reported to attack and or steal chicken that were found on free range. This was more so in the parish of Sikuda and Busitema. This predation has caused a big loss to the communities who feel like giving up on animal raring and poultry keeping. In this study, Bubango and Habuleke were the most affected parishes. This was the third most frequently reported conflict after crop raiding and habitat destruction (Table 3).

\section{Artificial Curfew}

In Habuleke and Bubango parishes water points and primary schools are not evenly distributed. Some pupils cross one village to another to go to school or collect water using paths near and or through the forest. Because these pass near the habitats of the baboons, the baboons interpret it as interruption. They therefore stage along the foot paths to scare away humans especially women and children there by imposing an artificial curfew at some times of the day. This is more so between midday to $2 \mathrm{pm}$ and 6.30 to $7 \mathrm{pm}$. This curfew has been seen as a punishment and invasion of human rights to access resource use like fetching water. This affected most Habuleke and Bubango parishes/clusters

\section{Human Attack}

Some women and children who go illegally collecting firewood from the forest are usually attacked by baboons. The most aggressive type reported was the olive baboons of Papio anubis specie. The baboons undermine women more than any other humans. The baboons usually chase and run after women who move in solitary during firewood collection. Some baboons were reported to occasionally come close to human settlements and steal very young children, carry them to the forest. This human attack has sometimes caused loss of life and is therefore intolerable by communities in question. This was reported in the parishes of Bukhubalo and Habuleke.

\section{Habitat Destruction}

On the other hand, wildlife is in conflict with humans who have encroached on their habitats by cutting down the trees and clearing the shrubs where the animals have been hiding. Substituting trees and 
shrubs with crop gardens has denied animal's habitat. This has decreased the carrying capacity of the forest, leading to scarcity of food, habitation and therefore reduction in population of monkeys, baboons and rodents. The rodents that can't adapt to a reduced habitat have extended to reside in crop gardens where they have barrowed to create new homes. This was more so in the parishes of Chawo and Amonikakeni.

\section{Poisoning}

Despite the fact that humans have extended their crop farms and homesteads near the forests, have not cared for their poultry leaving them on free range, humans who have lost their crops, animals and poultry to the wildlife have resorted to poisoning them. This has come with a reduction in the number of baboon and monkey species while the less affected were the rodent species. This was common in the parishes of Busitema, Syanyonja, Buhumi and Buhobe. Road accidents. The roads constructed through the forest such as Jinja-Tororo high way and Busia-Busitema-Jinja highway. Wildlife have led to physical killings of monkey and baboon species in road accidents. A number of approximately 15 animals per year were said be losing their lives to car accidents. This was more in Busitema, Bubango, Bukhubalo and Habuleke that are crossed by road networks (Figure 1).

There has also been trapping and physical killings of animals that stray in people's gardens. Snares are set in gardens to capture the straying wild animals so that they are killed to reduce the number of those raiding crops. This is usually done in human anger and as a preventive measure by the communities around Busitema Central Forest Reserve. This was more rampant in the Habuleke cluster

\section{Sustainable Human-Wildlife Management Strategies Around Busitema Central Forest Reserve}

The respondents were asked to propose human-wild life conflict management strategies that should be adopted by the forest management to ensure harmonious co-existence between the community and wildlife. The results are presented in Table 4.

Table 4: Variations in responses (mean \pm standard deviation) about Sustainable Human-Wildlife coexistence strategies from the ten study clusters around Busitema Central Forest Reserve

\begin{tabular}{ll}
\hline Strategy & $\begin{array}{l}\text { Variation of responses from ten clusters (mean } \pm \text { standard } \\
\text { deviation) }\end{array}$ \\
\hline Day and Night guarding & $7 \pm 2.1$ \\
Boundary demarcation (live hedges) & $7 \pm 0.9$ \\
Equitable compensation & $10 \pm 0.0$ \\
Community involvement & $8 \pm 1.4$ \\
Deployment of game police & $6 \pm 0.9$ \\
Management burning & $8 \pm 1.3$ \\
Strict laws & $4 \pm 2.7$ \\
Speed limit in the protected area & $3 \pm 2.2$ \\
\hline
\end{tabular}

Day and night guarding was suggested by $7 \pm 2.1$ respondents. This scares away the straying animals to avoid losses. The guards deployed may be local people or family members protecting crop gardens and livestock on shift basis. Every farmer should safeguard their gardens either physically or by use of scarecrows. A scarecrow resembling a human being is left in the crop garden and each time an animal looks at the scarecrow, it sees a person and goes away. In this, the crop gardens will be safe from wild life. 
Because there are no clear-cut boundaries between the forest reserve and surrounding local community's land, planting live hedge fences around the forest reserve would control some of the animals from straying in gardens. If farmers also protected their gardens by planting live hedge fences around their gardens especially those neighbouring the protected area, this will reduce on the rate of crop raiding save for monkeys that are more of climbers. Demarcation will also protect the poultry from mongoose. It will also indicate to communities' points beyond which they should not encroach. This suggested by $7 \pm 0.9$ respondents (Table 4).

$10 \pm 0.0$ respondents suggested that, for people who lose their crops, domestic animals and poultry to wildlife from Busitema Central Forest Reserve, an equitable and fair compensation should be offered to the losers. This should be based on assessment of damage caused. The only task for a bereaved person should be to report a crop raiding case to the UWA and NFA resource economist who should assess the impact/damage, and compensation takes effect. Compensation was also said to work if people close to the forest fringes are resettled elsewhere, creating a bigger game reserve of about $5 \mathrm{~km}$ radius between the human communities and the forest. With this, humans will be comfortable living in harmony with wildlife.

Community involvement in safe guarding the wild life. $8 \pm 1.4$ of the respondents indicated that, the local communities know which animals stray in which gardens and direction at which times of the day or season. These are the best to employ in chasing the animals back to the protected area. The local communities however can best do this if they are motivated. This motivation may be in form of cash back. When tourists come to visit the forest game like baboons and monkeys, they pay for the services. So, part of this money paid should come back to the communities around the forest reserve. This has not been the case for Busitema Central Forest Reserve yet it is tourist destination centre.
This will indicate a direct benefit to the community from the wildlife which in turn will make the communities appreciate and protect the wildlife to live in harmony.

Like in National parks, NFA and UWA should deploy game police (managers) to routinely patrol the forest reserve and monitor illegal activities taking place around and inside the forest such as firewood collection, deforestation and illegal grazing. These will be immediate and full-time custodians for the forest wild game that will safeguard the life of wildlife. This was suggested by $6 \pm 0.9$ respondents and was the second least mentioned of all responses (Table 4).

Management burning. Burning of the outskirts of the forest reserve especially where the forest terminates into grassland and thickets can be of importance. This burning controls the spread and straying of rodents into gardens and poultry houses in the surrounding areas of the protected area. Management burning creates a ring of little or no vegetation around the protected area and is controlled in such a way that the fire does not gut the forest. This was suggested by $8 \pm 1.3$ respondents.

Strict laws scaring and deterring people from poisoning, accidental and or physically killing the animals. Even when animals stray in gardens, farmers should report and not kill. Strict punishments against killing a wild animal should include both imprisonment of humans who involve themselves in killing animals both physically or accidentally for minimum of 5 years per animal killed and financial penalty of 2-5million Uganda shillings per animal killed or both. This will protect the wild game from human - induced death. This however was not so welcome by many people, so was the least being supported by $4 \pm 2.7$ respondents (Table 4).

Respondents indicated that controlling speed of motorists running through the protected area would 
save many wild animals from accidents. A speed limit of $20 \mathrm{~km} / \mathrm{hr}$ would suffice. The speed control can be achieved in three ways-, installing either closely packed rumble strips or humps on the road at the start of the protected area and inside the protected, area aimed at breaking the speed of motorists. Erecting visible (sizeable) sign posts indicating permissible speed limits at the start of the protected area and inside the protected area. Employing traffic police that would patrol and ensure motorists respect the speed limit. This response appeared $3 \pm 2.2$ times.

\section{DISCUSSIONS}

\section{Frequency of Occurrence the Human-Wildlife Conflicts}

The results reveal that majority experience humanwildlife conflicts on a seasonal basis. This is view is also echoed by Naughton Treves (2005) who associated the occurrence and frequency of human wildlife conflicts, specifically crop-raids as dependents upon the availability, variability and type of food sources in the area, the level of human activity on a farm, and the type and maturation time of crops, as compared to natural food sources.

\section{Nature of Human-Wildlife Conflict around Busitema Central Forest Reserve}

Baboons were found to dominate human wildlife conflicts in Busitema central forest. This is in line with Mekonen (2020), who observed that Olive baboon (Papio anubis) was the most commonly reported crop raiders which cause more damage and ranked first followed by herbivorous animals. In the current study Respondents reported the Papio anubis species of baboons to be affecting 7 parishes (70\%) of the area studied. $100 \%$ of the respondents in the parishes of Habuleke, Bubango, Buhobe and Busitema indicated that baboons are a problem to their socio-economic well-being. This was followed by Colubus (black and white monkey) species. According to him, not all crops are equally affected by crop raiders. In the current study Maize, cassava and groundnuts are affected by almost all the wild animals including baboons, monkeys and rodents. Millet and rice are the least affected and usually affected by rodents. This is because some crops are liked by many animal species hence affected more than others.

Animals have studied the human interference pattern, so they raid the crop gardens very early in the morning and very late in the evening when humans have not yet reported to or have left the gardens. This is similar to what Mekonen (2020), stated that wild animals damage crops early in the morning and evening when people are absent near farmlands.

Maize is affected from the time the stalks/stems begin to stand, through the cob-bearing stage up to when the maize is ready for harvesting. Potatoes and cassava are raided by rodents and primates from the time of bearing root tubes. This does not differ from Guinness et al. (2014) who stated that different species cause different types of damage at different times of the year. This is due to differences in gestation periods of different crops

Livestock and poultry predation. Hyenas were reported in some parishes to be a threat to lambs and kids. Scarcity of good in the forest forces Hyenas out of the forest that find tied grazing domestic animals, attack and kill them for food. Mongooses were also reported to attack and or steal chicken that were found on free range. This is in agreement with Mekonen (2020), who indicated that, Carnivores attack domestic livestock due to declining number of herbivorous in the wild due to prolonged droughts and habitat degradation.

Artificial Curfew. Baboons stage along the foot paths to scare away humans especially women and children going to fetch water from boreholes, as well as those collecting firewood there by imposing an artificial curfew at some times of the day. This act of animals is in defence of their habitats and family invasion. This is more so between midday to 
$2 \mathrm{pm}$ and 6.30 to $7 \mathrm{pm}$. This is not different from Sitati et al. (2012) who indicated that elephants paused indirect threats and imposed curfews on school children and local residents through being closer to roads leading to schools and surrounding forests, further hindering access to essential social, cultural and economic services.

Human attack. The baboons usually chase and run after women who move in solitary. Some baboons were reported to occasionally come close to human settlements and steal very young children, carry them to the forest, cause damage to them. This is usually during the dry season when food is scarce. The intention is to devour the children. This is consonance with Chapron et al. (2000) who observed that an assessment of the scale of human deaths caused by wildlife species in Africa at the end of the seventies, concluded that hippopotamus was responsible for more deaths than any other large animal in Africa

Habitat destruction. Substituting trees and shrubs with crop gardens has denied animal's habitat, decreased the carrying capacity of the forest, leading to scarcity of food, habitation and therefore reduction in population of monkeys, baboons and rodents. The rodents that can't adapt to a reduced habitat have extended to reside in crop gardens where they have barrowed to create new homes thereby spreading the conflict. This is in line with Hill et al. (2000) who observed that tree cutting was mainly associated with new settlement, which resulted deterioration of the remaining vegetation cover of the area minimizing the feeding ground, nesting and mating site of the wild animals.

Trapping in snares. There has also been trapping and physical killings of animals that stray in people's gardens. Snares are set in gardens to capture the straying wild animals so that they are killed to reduce the number of those raiding crops. This is because when losses are incurred, there is no compensation on the side of the farmer. So that's why farmers resort to physical killing of the animals, an argument that is similar to that reported by Hill et al. (2000) who indicated that, the inability to mitigate crop-raiding and absence of composition for crop losses lead to killing of animals.

\section{Sustainable Human-Wildlife co-existence strategies around Busitema Central Forest Reserve.}

It was suggested that, if farmers protected their gardens/farms by planting live hedge fences around their gardens especially those neighbouring the protected area, this will reduce on the rate of crop raiding. This will also protect the poultry from mongoose. A similar suggestion had been implemented earlier as reported by Musyoki et al. (2014) that in Kenya, the fencing of farms to keep wild animals away had created physical barriers for migratory species of zebras and wild beast.

Day and night guarding was suggested by $7 \pm 2.1$ respondents. This is known to scare away the straying animals to avoid losses. The guards deployed may be local people or family members protecting crop gardens and livestock on shift basis. Every farmer should safeguard their gardens either physically or by use of scarecrows. This concurs with Hill et al. (2000) who observed that active guarding by famers and members of their families was found to be the sole mode of protection from crop raiding.

$10 \pm 0.0$ respondents suggested that, for people who lose their crops, domestic animals and poultry to wildlife from Busitema Central Forest Reserve, an equitable and fair compensation should be offered to the losers. This should be based on assessment of damage caused. This suggestion has already started working in Kanha - India where an official compensation paid from 2006-2011 to 524 households inside the PA was $\$ 84$ and higher than the $\$ 63$ compensation that was paid to 1644 households located in the buffer (Naughton et al., 2003). 
$8 \pm 1.4$ of the respondents indicated that, the communities know which animals stray in which gardens and direction at which times of the day. These are the best to employ in chasing the animals back to the protected area. The local communities however can best do this if they are motivated. This agrees with Woodroffe et al. (2005) who indicated that it is very important that farmers be involved in the process of developing new conflict resolutions from the beginning. Not only does this foster a sense of commitment and involvement amongst them, but it is also vital that they be involved from the beginning. Because they understand how the situation affects them and what kinds of intervention are likely to be acceptable and feasible.

\section{CONCLUSION}

If sustainable conservation of wildlife in Busitema Central Forest Reserve is to be implemented for sustainable tourism activities and sustainable coexistence between humans and wildlife, sustainable strategies need to be adopted, so that the number of primate individuals, species and families stop declining towards extinction. For example, Areas surrounding the forest protected area should be planted with crops such as tea, and trees such as eucalyptus (woodlots) that are not affected by wildlife but rather are enhancers of wildlife habitats. Local human communities should be involved in safe guarding the wild life since these communities know which animals stray in which gardens and direction at which times of the day. The local communities however can best do this if they are motivated. This motivation may be in form of cash back (shared revenue) accrued from tourist activities in Busitema Central Forest Reserve.

\section{ACKNOWLEDGEMENT}

We are thankful to the Busia District environment office and the Uganda tourism board for the assistance you rendered to us in form of permission to carry out research and the information provided about forest and the Human-Wildlife Conflict to that effect.

\section{REFERENCES}

Chapron, G., \& López-Bao, J. V. (2020). The place of nature in conservation conflicts. Conservation Biology, 34(4), 795-802.

Erxleben, D. R., Butler, M. J., Ballard, W. B., Wallace, M. C., Peterson, M. J., Silvy, N. J., ... \& Dominguez-Brazil, M. K. (2011). Wild turkey (Meleagris gallopavo) association to roads: implications for distance sampling. European Journal of Wildlife Research, 57(1), 57-65.

Faulhaber, C. A., Silvy, N. J., Lopez, R. R., Lafever, D. H., Frank, P. A., \& Peterson, M. J. (2008). Diurnal habitat use by Lower Keys marsh rabbits. The Journal of Wildlife Management, 72(5), 1161-1167.

Forgie, V., Horsley, P. G., \& Johnston, J. E. (2001). Facilitating community-based conservation initiatives. Wallington, New Zealand: Department of Conservation.

Hill, C. M. (2000). Conflict of interest between people and baboons: crop raiding in Uganda. International journal of primatology, 21(2), 299-315.

Lusk, J. J., Guthery, F. S., Peterson, M. J., \& DeMaso, S. J. (2009). Long-term climate trends and northern bobwhite populations in South Texas. In National Quail Symposium Proceedings (Vol. 6, No. 1, p. 36).

McNally, X. (2017). Factors influencing conservation of local wildlife. Meliora: International Journal of Student Sustainability Research, 1(1).

Mekonen, S. (2020). Coexistence between human and wildlife: the nature, causes and mitigations of human wildlife conflict around Bale 
Mountains National Park, Southeast Ethiopia. BMC ecology, 20(1), 1-9.

MusyoKi, C. (2014). Crop defense and coping strategies: Wildlife raids in Mahiga'B'village in Nyeri District, Kenya. African Study Monographs, 35(1), 19-40.

Naughton-Treves, L. I. S. A., Grossberg, R., \& Treves, A. (2003). Paying for tolerance: rural citizens' attitudes toward wolf depredation and compensation. Conservation biology, 17(6), 1500-1511.

Ogada, M. O., Woodroffe, R., Oguge, N. O., \& Frank, L. G. (2003). Limiting depredation by African carnivores: the role of livestock husbandry. Conservation biology, 17(6), 15211530 .

Peterson, M. J., Hall, D. M., Feldpausch-Parker, A. M., \& Peterson, T. R. (2010). Obscuring ecosystem function with application of the ecosystem services concept. Conservation Biology, 24(1), 113-119.

Saito, F. (2007). Local Council commons management in Uganda: A theoretical reassessment. GSID Discussion Paper, (153), 121.

Sitati, N. W., Walpole, M. W., Leader-Williams, N., \& Stephenson, P. J. (2012). Humanelephant conflict: Do elephants contribute to low mean grades in schools within elephant ranges? International Journal of Biodiversity and Conservation, 4(15), 614-620.

Vijayan, S., \& Pati, B. P. (2002). Impact of changing cropping patterns on man-animal conflicts around Gir Protected Area with specific reference to Talala Sub-District, Gujarat, India. Population and environment, 23(6), 541559.

Woodroffe, R., Thirgood, S., \& Rabinowitz, A. (Eds.). (2005). People and wildlife, conflict or co-existence? (No. 9). Cambridge University Press. 